\title{
Role of the Media in Combating the Obnoxious Trend of Human Trafficking in Nigeria
}

Dennis Ugochukwu Omeonu, Samuel Okoronkwo Chukwu-Okoronkwo, Ikedieze Charles Enyinnaya

Department of Mass Communication, Abia State University, Nigeria

DOI: $10.36347 /$ sjahss.2020.v08i05.002

| Received: 24.04.2020 | Accepted: 01.05.2020 | Published: 09.05.2020

*Corresponding author: Dennis Ugochukwu Omeonu

\section{Abstract}

Human trafficking is one of the many other types of neo-slavery where people are lured, tricked or forced to work against their will for the enrichment of others. It has become a serious socio-economic problem with grave national and international implications.Every year, countless number of men, women and children are trafficked illegally all over the world. It is perhaps the most devastating physical and psychological trauma experienced by men, women and children of all ages. Unarguably, the media have been playing a formidable role in the effort to combat the obnoxious trend of human trafficking. Anchoring on the agenda-setting theory as well as survey research methodology approach, the study critically examines the indispensable role of the media in the effort to address the issue of human trafficking; while at the same time assessing audience respond to media coverage on the issue, focusing on Amassoma Community in Bayelsa State. Findings reveal, among others, that the prevailing economic condition of the country has a lot to do with causes of human trafficking. The paper concludes that the media have contributed so much in sensitizing the people about the scourge of human trafficking; thus widening their knowledge and understanding of its root causes. However, to help prevent the media outlets from becoming a conduit for the exploitation of people through their advertising for jobs and other services, the study also advances very useful recommendations.

Key words: Crime, human trafficking, media's role, neo-slavery, sensitization.

Copyright @ 2020: This is an open-access article distributed under the terms of the Creative Commons Attribution license which permits unrestricted use, distribution, and reproduction in any medium for non-commercial use (NonCommercial, or CC-BY-NC) provided the original author and source are credited.

\section{INTRODUCTION}

Despite the spirited efforts that led to the abolition of slave trade in early nineteenth century, "this inhuman trade has" now "re-emerged in the form of human trafficking[1]". Human trafficking is, therefore, a kind of neo-slavery where people are lured, tricked or forced to work against their will for the enrichment of others. Most often the victims of human trafficking are made to believe that they will be sent to school, secure well-paid jobs, run lucrative businesses overseas which will help to improve their standard of living. However, at the back of the minds of the traffickers, they will be engaged in degrading domestic work, child labour or forced labour or begging, prostitution, servile marriage and even ritual sacrifices. According to the International Labour Organization (ILO) assessment of human trafficking victims in the world, about 21 million victims are exploited in all the forms of this crime. The big question is: What role can the media play in the quest to combat the obnoxious trend of human trafficking? Information dissemination is essential to stopping slavery. In lending a voice to this necessity, FitzPatrick [2] argues that if the public cannot see the problems, it is difficult to mobilize financial and political support to solve human tracking, as visibility remains vital to building a vibrant, sustainable movement against it. Human trafficking, FitzPatrick maintains, is illegal; it is hidden from view, and has taken more than a decade of media relations work to convince the public that slavery really still exists. Persuading the world that human trafficking and indeed slavery can be eradicated is essential. To do that, effective media relations is just as important.

Trafficking is more than a technical problem that can be solved by trained professionals working quietly behind the scenes. Because slavery has many root causes - such as poverty, corruption and gender inequality political will is needed to implement many of the solutions. That's where the media come in. News coverage helps to bring to the mainstream a cause like abolition, by engaging people who do not frequent human rights websites. Millions of potential supporters would take a stand against slavery if they knew 
it existed and could be overcome. Their collective voice will help anti-slavery efforts to grow and succeed[2].

Nigeria has become one of the leading African countries in human trafficking with cross-border and internal trafficking. It is not only a point of origin, but also a transit and destination for human trafficking $[3,4]$. Destinations for trafficked Nigerians according to UNESCO include the neighbouring West African countries (Côte d'Ivoire, Mali, Benin, Equatorial Guinea, Cameroon, Gabon and Guinea), European countries (Italy, Belgium, Spain, the Netherlands, Germany and the United Kingdom), North Africa (Libya, Algeria and Morocco) and Middle Eastern countries (Saudi Arabia); and South America has also added to the list of points of destination for trafficked persons from Nigeria, particularly Venezuela. The media's role in creating awareness in human trafficking by churning out programmes in dramatized way, expressive reportage on human trafficking through films, print and broadcasting media is a worthwhile venture. Therefore, it is believed that the Nigeria mass media can through their campaign bring about a social change towards the despicable scourge named human trafficking.

\section{The Crux of the Matter}

By definition, human trafficking according to $\mathrm{UN}$ is: the recruitment, transportation, transfer, harboring or receipt of persons, by means of threat or use of force or other forms of coercion, of abduction, of fraud, of deception, of the abuse of power or of a position of vulnerability or of the giving or receiving of payments or benefits to achieve the consent of a person having control over another person, for the purpose of exploitation. Exploitation shall include, at a minimum, the exploitation or the prostitution of others or other forms of sexual exploitation, forced labor or services, slavery or practices similar to slavery, servitude or the removal of organs [5].

Corroborating the above UN definition from a Nigerian context, Okogbule (1) asserts:

in recognition of the multifarious nature of human trafficking, section 50 of the Trafficking Act provides a broad definition of trafficking by stating that it includes: "all acts and attempted acts involved in the recruitment, transportation within or across Nigerian borders, purchases, sales, transfer, receipt or harbouring of a person involving the use of deception, coercion or dept bondage for the purpose of placing or holding the person whether for or not in involuntary servitude(domestic, sexual or reproductive) in force or bonded labour, or in slavery-like condition”. (p.71)
Jones et al. [6] point to the huge and farreaching consequences of human trafficking for victims. First and foremost, it is a violation of human rights. Others include that victims are susceptible to being held in debt bondage and involuntary servitude, often being forced to work for low or no wages in unsafe and unregulated working conditions. They also often face ill treatment by public authorities that may associate them with criminal activity, such as prostitution or illegal immigration. The researchers also note that traffickers capitalize on this unfortunate fact to consolidate their power over victims, threatening them with arrest, imprisonment, and other official/legal actions if they do not remain subservient. In addition to the above:

human trafficking contributes to the weakening of social structures in sending countries by denying individuals access to their immediate and extended families... Macro consequences of trafficking for receiving countries include strengthening the hand of organized crime, which can put the overall security of the society at risk [6].

The United Nations office on Drugs and Crime (UNODC) [7] unequivocally sums up that the human and social consequences of trafficking are compelling. Thus, ranging from the physical abuse and torture of victims to the psychological and emotional trauma, to the economic and political implications of unabated crime, the impact on individuals and society is clearly destructive and unacceptable.

Every stage of the trafficking process can involve physical, sexual and psychological abuse and violence, deprivation and torture, the forced use of substances, manipulation, economic exploitation and abusive working and living conditions. Unlike most other violent crime, trafficking usually involves prolonged and repeated trauma. Documentation and research describe how men, women and children are abused in specific exploitative conditions and the shortand long-term physical injuries, disabilities and deaths that may result [7].

Human traffickers are obviously wolves in sheep clothing. They prey on people who are poor, isolated and weak and often come with pretended behaviour, sweet tongues and interesting lies; mostly the people that are unlawfully taken away from their homes are children and women from very poor background. Vulnerable youths who finished their higher education and failed to secure jobs in their home countries also fall prey to traffickers in their attempt to travel out and do anything in order to survive. Hence, unemployment could be ascribed as one of the main causes of human trafficking. Poverty, as already 
indicated, certainly also has its share of contribution to a number of cases of human trafficking as some unsuspecting poor parents are often deceived to think that their lot would be bettered by giving out their children to go and serve someone else for some remuneration only for such children to end up being exploited. This, perhaps, explains the reason for the rising incidents of child labour, child prostitution and its new trend of sex tourism [8] which is "organized with the primary purpose of facilitating the effecting of a commercial sexual relationship with a child" [9]; and thrives within and outside the country through trafficking.

Olojuwon [10] identifies further causes of human trafficking as including insatiable lust for money, materialism and discrimination (particularly against women, children and minorities), violence, general insecurity, internal displacement as a result of ethnic/religious crises, low level of education, particularly among women, that have greatly reduced the capacity of women in the formal labour sector, making them to seek another means of sustenance and forcing them into the hands of traffickers. According to 2018 Trafficking in Persons Report on Nigeria published by the United States Department of State, 1,121 potential trafficking victims, including 538 people in prostitution, 203 child labor victims - some of whom were forced - and 188 forced labor victims were identified. This was similar to 1,128 potential trafficking victims (529 people in prostitution, 165 child labor victims, and 434 forced labor victims) identified in the previous reporting period.

A briefing paper for the Special Rapporteur on Trafficking in Persons, especially in women and children, by the International Movement Against all forms of Discrimination and Racism (IMADR), in preparation for her mission to Nigeria corroborates reports [11, 12] of traffickers use threats of voodoo curses as a major characteristic of the Nigerian trafficking system meant to control victims and force them into situations of prostitution:

once arrangements for victims' trips abroad are completed, traffickers seal the deal by taking the victims to shrines of voodoo priests for oath taking. During the ritual, in which body parts such as fingernails, blood and/or pubic hairs are recollected, the woman is made to swear an oath to repay her debt, never to report her situation to the police or reveal the identities of her traffickers. Fear of breaking the pact is so strong that it creates a powerful hold over the victims and impedes them to seek help [13].

This indecent and ungodly act should not thrive in Nigeria if the provision of the United Nations Convention in 2000 and Nigeria 1999 Constitution is anything to go by, one can therefore agree that an average Nigerian is not much aware of the Child RightBill. Based on this premise, this paper highlights the danger which the obnoxious scourge of human trafficking portends to the development of our nation and what media are doing in combating this ugly trend. This is because of the researchers' strong belief that:

The mass media are key drivers for the spread of information, or misinformation about human trafficking. What we know or do not know determines our response to it, what is reported and how it is reported, goes some way in shaping the policy and State action agenda, and has implications for the traffickers and the trafficked. (Dr. Sarah Macharia, Program Manager for Gender and Communication, World Association for Christian Communication, on the role of media in addressing human trafficking in Canada and globally[14],

\section{Objectives of the Study}

This study sets out to:

1. Identify the strategies used by the media in their campaign against human trafficking.

2. To determine the extent of awareness of antitrafficking campaign by the media.

3. To ascertain the effect of anti-human trafficking campaign on the audience.

\section{Research Questions}

1. Do media human trafficking reports include using enabling public visibility through the right images, responsible advertising for services/jobs and respecting discretion with reference to personal information about victims?

2. To what extent are the public aware of human trafficking reports by the media?

3. What are the effects of human trafficking reports on the audience?

\section{Theoretical Framework}

This study is anchored on Agenda-setting theory. One of the main assertions of agenda setting theory is that what the media find important or salient is what the public finds important [15]. Agenda-setting is the selective coverage of topics that lead the public to perceive some issues as more important than others regardless of their inherent news worthiness [16]. A second aspect of Agenda-setting theory is known as second level agenda setting, which is the idea that the mass media not only tell people what to think about certain issues but also how to think about them [17].Agenda-setting theory can illuminate our understanding on the effect of mass media message. This theory states that media may not tell us what to think, but media certainly tells us what to think about. Dominick [18] during the era of the limited effects, 
infers that several ideas were developed that began to cast some doubt on the assumption that the media and culture influence on people was minimal. The media can set the agenda of the human trafficking campaign as audience will learn about the issue from the media contents and its positions on the anti-human trafficking campaign. Agenda-setting theory is much profound in circumstance where the audience needs orientation or knowledge. This could be achieved only when the mass media persistently sensitize the populace through the mass media outlets, especially those in the rural areas. Information makes meanings only when they are used to meet the priorities of the people regarding information in context that fit their ideology [19]. How audience responds to mass coverage of human trafficking is equally the focus of this study. Public opinion on social issues is not only shaped by mass media but can also influence the agenda of the media and polities. Audience supports their role of active recipients by observing newsworthy events and spreading the news afterwards by applying their personal filter [20]. Good human trafficking reports will ever make impact in curbing the menace of human trafficking. Recent technological advances allow citizens with internet access to not only actively interpret and interact with web-based content, but also to broadcast their own interpretation of events.

\section{METHODOLOGY}

The study employs the survey research approach. Surveys allows for the study of people's opinion over a given issue of national concern. The area of study is Amassoma Community in Bayelsa State. The choice of Amassoma is informed by the fact that it is one of the fastest growing areas of Southern Ijaw Local Government Area of Bayelsa State. Also, the residents are privileged to have in place a number of television channels, radio stations as well as print media outlets.

\section{Population of the Study}

The population of the study is drawn from two sections of Amassoma Community comprising of Central Amassoma and Niger Delta University, Wilberforce Island/Alamco Road.

\section{Sample Size and Sampling Technique}

A sample size of 200 respondents was carefully selected from two sections of the area for the purpose of the study. Each of the two sections was issued with 50 (fifty) copies of questionnaire, while another one hundred went to the media practitioners working within the area. The sampling technique employed was the random technique, which impacted on the representatives of the sample to ensure inclusion of diverse groups in the population. To elicit required responses from respondents, two sets of structured questionnaire were employed. One was administered to the audience within these selected zones. The other set of questionnaire was for the media practitioners who sought to elicit data for the strategies used by the practitioners in their human trafficking reports, whereas the questionnaire for mass media audience, sought to elicit, demographic information of respondents and their level of awareness on human trafficking reports.

\section{Method of Data Analysis}

The researchers employed simple percentage and frequency values to analyze collected data.

\section{Data Presentation and Analysis}

One hundred (100) copies of questionnaire were issued to media practitioner and another hundred (100) issued to media audience, totaling two hundred (200). Out of this total number, one hundred (100) were turned in by media practitioners while ninety (90) were retrieved from media audience.

The data presented here answer the research questions raised in the study.

\section{Questions for Media Practitioners}

Fig. 1 provides answers to research question one (1) of the study as directed to media practitioners:

Do media human trafficking reports include using enabling public visibility through the right images, responsible advertising for services/jobs and respecting discretion with reference to personal information about victims? These answers which substantiate the above research question are contained in responses by media practitioners to sub-questions $\mathrm{a}, \mathrm{b}$ and $\mathrm{c}$ below as further illustrated in the figure.

- Sub-question a (SQ a): Do you employ the use of enabling public visibility through the right images in your human trafficking report?

- $\quad$ Sub-question b (SQ b): How responsible is media advertisement in connection with information for services/jobs? Do you think they are conduit for exploitation?

- Sub question c (SQ c): Do the media promote discretion with reference to personal information about victims? 


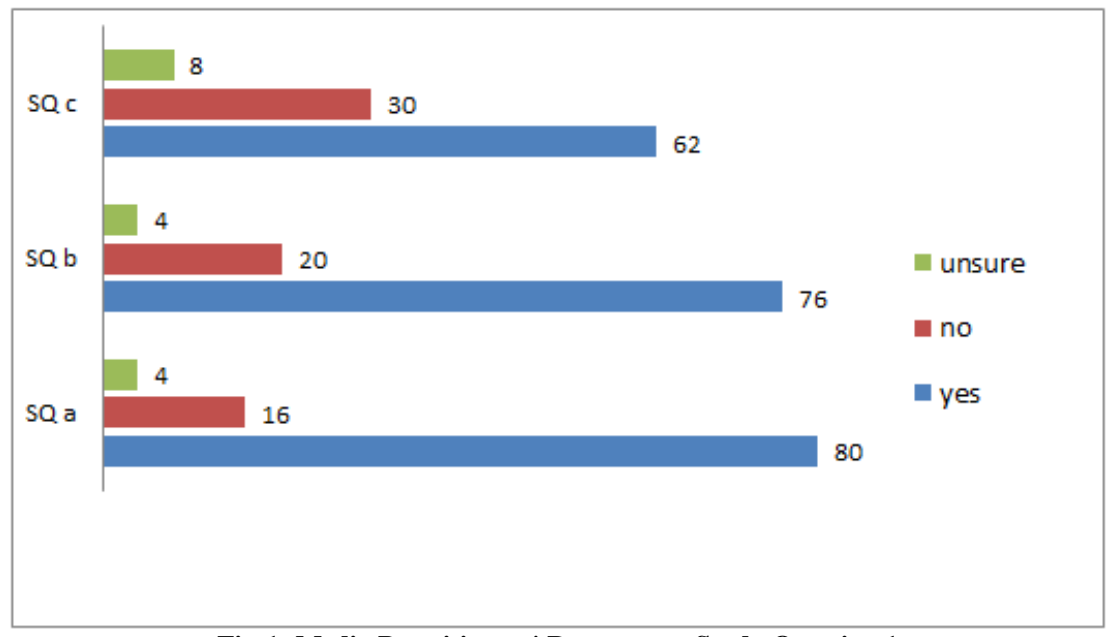

Fig-1: Media Practitioners' Response to Study Question 1

The figure above indicates that for subquestion a (SQ a), $80 \%$ of the respondents affirmed that using images as powerful tool in helping audience visualize the crime of human trafficking is the responsibility of the media outlets. $16 \%$ answered in the negative to the question, while $4 \%$ were unsure. For sub-question b (SQ b), 76\% of the respondents agreed that advertisement in the print or online and broadcast media provide information for services/jobs which can sometimes result into exploitation of trafficked victims. $40 \%$ answered in the negative to the question, maintaining that media outlets are not conduit for the exploitation of people; while $4 \%$ were unsure of the position of media in their advertisement for services/jobs. For sub-question c SQ (c), 62\% of the respondents affirmed that media respect discretion with reference to personal information about victims, prioritizing their anonymity. $30 \%$ maintained that there are challenges in covering human trafficking news in which case the anonymity of victims are not properly guided, while $8 \%$ were not sure of the respect to victims information considering their difficulty to reintegrate into society and the possibility of their re-victimization being always present.

\section{Questions for Media Audience}

Tables $1 \& 2$ provide answers to research questions two (2) of the study: To what extent are the public aware of the human trafficking reports by the media? These answers which substantiate the above research question are contained in responses by media audience to sub-questions $\mathrm{a}$ and $\mathrm{b}$ below as further illustrated in the tables.

Table-1: Sub-question a (SQ a): Do you think that the media have contributed to anti-human trafficking?

\begin{tabular}{|l|l|l|}
\hline Options & Frequency & Percentage \\
\hline Yes & 48 & 53 \\
No & 25 & 28 \\
Unsure & 17 & 19 \\
\hline Total & $\mathbf{9 0}$ & $\mathbf{1 0 0}$ \\
\hline
\end{tabular}

From the table above, 48 respondents representing 53\% affirmed media's contribution to antihuman trafficking. 25 respondents representing $28 \%$ were not aware of any contribution of the media towards anti-human trafficking reports, while 17 respondents representing $19 \%$ were unsure about what the media have contributed to this effect.

Table-2: Sub-question b (SQ b): What medium/media were you made aware of human trafficking?

\begin{tabular}{|l|l|l|}
\hline Options & Frequency & Percentage \\
\hline Radio & 35 & 39 \\
Television & 21 & 23 \\
Newspaper & 18 & 20 \\
Online & 16 & 18 \\
\hline Total & $\mathbf{9 0}$ & $\mathbf{1 0 0}$ \\
\hline
\end{tabular}

From the above table, 35 respondents representing $39 \%$ were aware of human trafficking through radio; 21 respondents representing 23\% through television; 18 respondents representing $20 \%$ through newspapers and 16 respondents representing $18 \%$ through online (social media).

Tables 3 \& 4 provide answers to research question three (3): What are the effects of human trafficking reports on the audience? These answers which substantiate the above research question are contained in responses by media audience to subquestions $\mathrm{a}$ and $\mathrm{b}$ below as further illustrated in the tables.

Table-3: Sub-question a (SQ a): What do you think from your awareness of human trafficking are the root causes?

\begin{tabular}{|l|l|l|}
\hline Options & Frequency & Percentage \\
\hline Poverty & 60 & 67 \\
Unemployment & 20 & 22 \\
$\begin{array}{l}\text { False hope of working } \\
\text { abroad }\end{array}$ & 10 & 11 \\
\hline Total & $\mathbf{9 0}$ & $\mathbf{1 0 0}$ \\
\hline
\end{tabular}


From the table above, 60 respondents representing $67 \%$ affirmed that the awareness created by the media on human trafficking made them realize that poverty is one of the causes of people being lured into travelling abroad where they are enslaved afterwards. 20 respondents representing $22 \%$ agreed that the awareness created by media opened their eyes to know that vulnerable youths who finished higher education and failed to secure jobs out of unemployment always fall victims of human trafficking; while 10 respondents representing $11 \%$ equally affirmed that the awareness by the media made them to know that false hope of working or continuing their education abroad has always been the cause of people falling victims in the hands of human traffickers.

Table-4: Sub-question b (SQ b): What do you think are the consequences of human trafficking?

\begin{tabular}{|l|l|l|}
\hline Options & Frequency & Percentage \\
\hline Loss of human resources & 30 & 33 \\
Life of crime & 25 & 28 \\
$\begin{array}{l}\text { Weakening of family } \\
\text { love and influence }\end{array}$ & 35 & 39 \\
\hline Total & $\mathbf{9 0}$ & $\mathbf{1 0 0}$ \\
\hline
\end{tabular}

From the table above, 30 respondents representing $33 \%$ affirmed that there is a great loss in human resources because most of the victims of human trafficking fall within the age bracket of 16 years and 60 years. 25 respondents representing $28 \%$ affirmed that majority of the victims of human trafficking turned bad because they were exposed to criminal acts such as drug addiction, theft and involvement in sexual assault or violence; while 35 respondents representing 39\% affirmed that out of the awareness created by the media they were able to notice that the victims are deprived of family love. Also, the risk and unlawful nature of the business of human trafficking expose people to untimely death, imprisonment and confiscation of property.

\section{Findings}

The study is aimed at identifying the strategies used by the media in their human trafficking reports as well as to determine the extent of awareness and the effect of human trafficking reports on the audience. Findings reveal that the media use images as a powerful tool in helping audience visualize the crime of human trafficking. This is simple making issues relating to human trafficking visible to the public. Hence, the importance of visibility in tackling human rights challenge like human trafficking cannot be overemphasized. FitzPatrick [2] reinforces this reality by maintaining that human trafficking is illegal and hidden from view, and if the public cannot see the problem, then it would be difficult to mobilize support to solve it. It was equally discovered that sometimes information for services/jobs, result into exploitation of trafficked victims. The study found that media in their human trafficking report respect discretion with reference to personal information about victims, prioritizing their anonymity, as lack of realistic validation of cases of human trafficking only gives room for narrating of such stories. However, the study found that media have helped in sensitizing the people about the scourge of human trafficking. The effect of this sensitization has thrown more light on the people's knowledge of the root causes of human trafficking with regard to false hope of continuing education or working abroad, poverty and unemployment. The consequences are also brought to the fore by the media, as the people realized that loss of human resources, life of crime, and weakness of family love and influence among others are the consequences of human trafficking.

\section{CONCLUSION}

Based on the above findings, it is quite comprehensible that the key role of awareness raising which the media play in human trafficking issues is done through using images as powerful tool in helping audience visualize the crime of human trafficking, responsible advertising and promotion of discretion as they dig deeper into the issue of human trafficking, aiming to portray it more responsibly, sensitively and ethically. However, the prevailing economic condition in Nigeria is also identified as having a lot to do with the root causes of human trafficking as exposed by the media. Also, the awful consequences of human trafficking as equally exposed by the media include loss of human resources, life of crime, weakening of family love and influence among others.

\section{RECOMMENDATIONS}

Based on the observations highlighted in the study, the researchers recommend as follows:

- In order to help in preventing media outlets from becoming sort of conduit for the exploitation of people, they should be empowered to have the potential to follow these principles.

- Provide trafficking hotlines.

- Cooperate with police in investigations where they are able

- Those who are interested in obtaining adult services must be aware that they may encounter victims of trafficking. They must also be aware of where to report any of such suspicions.

- Owing to media ability to mould public opinion, they are powerful tool of social change. Investigative journalism on trafficking needs to be promoted.

- Responsible scrutiny by international media can be the difference between trafficker being released or imprisoned.

- The government should be committed in addressing issues concerning poverty, unemployment, gender based abuse and education. 


\section{REFERENCES}

1. Okogbule, N. Combating the "new slavery" in Nigeria: An appraisal of legal and policy responses to human trafficking. Journal of African Law. 2013; 57(1), 57-80.

2. FitzPatrick, T. How to ... use the media to help combat human trafficking, 2013. Available from https://www.theguardian.com/global-developmentprofessionals-network/2013/jun/03/anti-traffickingcommunications-tips [accessed 20 April, 2020].

3. UNESCO. Human trafficking in Nigeria: Root causes and recommendations. Policy Paper Poverty Series; 2006, NO.14.2 (E). Paris: UNESCO.

4. United States Department of State. Trafficking in Persons Report - Nigeria, 28 June 2018, available at:

https://www.refworld.org/docid/5b3e0ab6a.html [a ccessed 16 April, 2020]

5. United Nations. Protocol to prevent, suppress and punish trafficking persons, especially women and children, supplementing the United Nations convention against transnational organized crime. 2000; available fromhttps://www.ohchr.org/en/professionalinterest/ pages/protocoltraffickinginpersons.aspx [accessed 17 April, 2020].

6. Jones L, Engstrom DW, Hilliard T, Diaz M. Globalization and human trafficking, The Journal of Sociology \& Social Welfare.2007; 34(2):107122.

7. United Nations office on Drugs and Crime (UNODC). An introduction to human trafficking: Vulnerability, impact and action. New York: United Nations; 2008.

8. Chukwu-Okoronkwo SO, Okoronkwo NE. Child Abuse and Prostitution Phenomena: Critical Issues in Nigeria's Sustainable Development. American Journal of Environment and Sustainable Development. 2017;2(3):16-22.

9. Terrero LS. Social Impacts of tourism in Brazil. Global Sustainable Tourism Review (GSTR). 2014:79-94.

10. Olujuwon T. Combating trafficking in person: A case study of Nigeria. European journal of scientific research. 2008;24(1):23-32.
11. Siddharth K. Sex trafficking: Inside the business of modern slavery. New York: Colombia University Press. 2009.

12. Harrop EW. A bewitching economy: witchcraft and human trafficking, 17 September 2012, Think Africa Press.

13. International Movement Against all forms of Discrimination and Racism (IMADR). Human trafficking in Nigeria: Briefing paper for the special rapporteur on trafficking in persons, especially in women and children. Geneva: IMADR, 2015. Available fromhttps://imadr.org/wordpress/wpcontent/uploads/2016/01/IMADR-Briefing-

Paper_Human-Trafficking-inNigeria_5.11.2015.pdf [accessed 18 April, 2020].

14. WACC. Human trafficking and the role of media, June 27, 2017, available from http://www.waccglobal.org/articles/humantrafficking-and-the-role-of-media [accessed 19 April, 2020]

15. Marchionni DM. International human trafficking: An agenda building analysis of the US and British press. International Communication Gazette. 2012; 74(2):145-158.

16. Wanta W, Golan G, Lee C. Agenda setting and international news: Media influence on public perceptions of foreign nations. Journal of Mass Communication Quarterly. 2004, 81(2): 364-377.

17. McCombs M, Shaw D. The evolution of agendasetting research: Twenty five years in the market place of ideas. Journal of Communication. 1993; 43(2): 58-67.

18. Dominick J. The Dynamics of Mass Communication. Baltimore: McGraw-Hill Inc; 2002.

19. Okunna SC. Teaching mass communication: A multi-dimensional approach. Enugu: New Generation Book, 2002.

20. Hermida A, Thurman N. Comments: How the British news media are struggling with usergenerated content. Paper presented at the 8th International Symposium on Online Journalism; 2007. 